\title{
Correction to: Analysis of Seasonal Precipitation, Potential Evapotranspiration, Aridity, Future Precipitation Anomaly and Major Crops at District Level of India
}

\author{
Laxmi Goparaju' $^{1}$ (D) Firoz Ahmad ${ }^{1}$ (D)
}

Published online: 4 December 2019

(c) The Author(s) 2019

\section{Correction to: \\ KN - Journal of Cartography and Geographic Information (2019) 69:143-154 \\ https://doi.org/10.1007/s42489-019-00020-4}

The article Analysis of Seasonal Precipitation, Potential Evapotranspiration, Aridity, Future Precipitation Anomaly and Major Crops at District Level of India, written by Laxmi Goparaju and Firoz Ahmad, was originally published electronically on the publisher's internet portal on 5 June 2019 without open access.

With the author(s)' decision to opt for Open Choice, the copyright of the article changed in December 2019 to (C) The Author(s) 2019 and the article is forthwith distributed under the terms of the Creative Commons Attribution 4.0 International License (http://creativecommons.org/licenses/ by/4.0/), which permits use, sharing, adaptation, distribution and reproduction in any medium or format, as long as you give appropriate credit to the original author(s) and the source, provide a link to the Creative Commons license and indicate if changes were made.

The original article has been corrected.

Open Access This article is licensed under a Creative Commons Attribution 4.0 International License, which permits use, sharing, adaptation, distribution and reproduction in any medium or format, as long as you give appropriate credit to the original author(s) and the source, provide a link to the Creative Commons licence, and indicate if changes were made. The images or other third party material in this article are included in the article's Creative Commons licence, unless indicated otherwise in a credit line to the material. If material is not included in the article's Creative Commons licence and your intended use is not permitted by statutory regulation or exceeds the permitted use, you will need to obtain permission directly from the copyright holder. To view a copy of this licence, visit http://creativecommons.org/licenses/by/4.0/.

The original article can be found online at https://doi.org/10.1007/ s42489-019-00020-4.

Firoz Ahmad

adfiroz@yahoo.com

Laxmi Goparaju

goparajulaxmi@yahoo.com

1 Vindhyan Ecology and Natural History Foundation,

Mirzapur, Uttar Pradesh, India 